\title{
Rereading about the interfaces of feminism in the socio-cultural tries of women
}

\author{
Kathyelle Ninfa Moneta Souza do Amaral ${ }^{1 *}$; Fabiane Gonçalves ${ }^{2}$ \\ 1 Bachelor's degree in Psychology at FACHO (Faculty of Human Sciences of Olinda) - Pernambuco - Brazil. \\ 2 Master in Cognitive Psychology from the Federal University of Pernambuco. She is an Adjunct Professor in the Department of Psychology \\ at the Faculty of Human Sciences of Olinda. He has experience in Psychology, with emphasis on Cognitive and Clinical Psychology, working \\ mainly on the following topics: Language, Body, Gender, Development and Culture
}

E-mail adresses: kathyelleamaral@gmail.com (Kathyelle Ninfa Moneta Souza do Amaral), fabianemsg@facho.br (Fabiane Mônica Gonçalves),

${ }^{*}$ Corresponding author

\section{To cite this article:}

Amaral, K.N.M.S.; Gonçalves, F.M. Rereading about the interfaces of feminism in the socio-cultural tries of women. International Journal of Sciences. Vol. 1, No. 3, 2021, pp. 90-95. ISSN 2763-5392

Received: 05 10, 2021; Accepted: 05 10, 2021; Published: 05 24, 2021

\begin{abstract}
The historicity of women in different places and their trajectory are ideal to be analyzed, including when they were subjected to lower conditions, to the moment they went in search of their rights, aiming to articulate the feminist movement to the perspective of existential psychology before these women. The aim of this article is to investigate feminism in the light of existential psychology, understanding the historicity of women, the interfaces of the feminist movement and its sociocultural aspects. A study of narrative bibliographic review was carried out, with a qualitative approach. It was found that through the compression of women's history and the understanding of how it is constituted in the past, they are revealed of their attitudes in the present, relate their actions and thoughts from existentialism, in order to understand how these women are in the world, especially in the relationship between existentialism and feminism.
\end{abstract}

Keywords: History of Women. Feminist movement. Existentialism.

\section{Introduction}

It is proper to all transformative praxis, raising theoretical, political and social questions as a permanent result of its process of scientific construction, and Psychology as a science, does not shy away from this paradigm, especially because of the assumption that feminism is a emancipation movement, based on the abolition of oppressive restrictions and redistribution of power (GONÇALVES; YAMAMOTO, 2015).

With regard to feminism, it is understood as a historical process of sociopolitical claims, focused on the struggle for gender equity in all contexts and equal opportunities for women and men, which serves as a gateway to social reforms and transformations (BARBOSA, 2016).

According to Garcia (2010), although common sense erroneously links the term feminism to a dispute between genders (men versus women), the feminist movement appears as an opposition to machismo and inequality between genders, with the purpose of providing women with dignity and citizenship. It is worth adding that the movement seeks to redefine the identity of sex, contesting the incessant search for adaptations to hierarchical patterns, where there are separations of qualities and defects according to gender.

In Brazil, the feminist movement was organized under the military regime, in the (suffragist) struggle for the right to vote, and until today it is in evidence through demands in different areas, starting from the defense by the less favored categories and mainly women (DOMINGUES, 2020). It should be noted that, through public movements and concerns, women have become increasingly notorious spaces, however, some issues involving equality are still challenges to be overcome, such as the standardization of machismo, disparities in positions and salaries, gender violence and among other aspects (VILARIM; GOMES, 2020).

In psychology there is an approach called existentialism, which arose from the ideas advocated by Kierkegaard, a philosophical and literary aspect which had theoretical allies such as Heidegger and Jean-Paul Sartre (SCHNNEIDER, 2011). The perception of traditional existential phenomenology about reality for them refers to a world of possibilities, where the human being with his freedom of expression and choices chooses what is convenient for him (SOUZA et al., 2020). 
In this context, Simone de Beauvoir, the companion of the existentialist philosopher Sartre, emerges, who broke with traditional bases and implanted her feminine idea of the lived body, constituting itself as a reliable phenomenology of the experience of women in their gender specificity, using the interlocution between the I and the Other, the corporeity and sexuality, as the deconstruction that identifies the female subject (OLIVA, 2014).

In the scientific sphere, it can be emphasized that there are some literatures that address feminism; however, few studies relate it to the existentialist approach in a directive way. Thus, in addition to the above, this article aims to conduct a narrative bibliographic review, in order to understand feminism in the light of existential psychology, analyzing the historicity of women, the interfaces of the feminist movement and its sociocultural aspects.

\section{Methodology}

This is a bibliographic narrative review study, with a qualitative approach, which uses materials already published, where its main advantage is to allow the researcher a broad view of the phenomena studied (PEREIRA; PARREIRA; SHITSUKA, 2018). The research procedure assigned the form, which promotes pain research, greater organization and safety in its data investigation.

The research was carried out from materials published and available in databases such as Google Scholar and Virtual Health Library (VHL), using the following descriptors: History of Women; Feminist movement; Existentialism and Psychology.

As inclusion criteria were assigned studies that had feminism as their theme in the light of existential psychology and excluded publications published as simple abstracts in the annais of scientificevents. Initially, the titles and abstracts of the materials found were analyzed, and the studies were refined and the most consistent ones were selected according to the theme of this review.

\section{Results and Discussion}

\section{Feminism and existentialism}

Throughout the history of mankind, one could perceive the differences in education introjected in men and women, so that the man was always directed to command and the woman taught to serve him, occupying, the woman, a place of subordination. As a single woman, she was the father's possession and when she married the function became her husband's, thus not being allowed her freedom and autonomy. Due to the patriarchal family structure and morphological differences between the sexes (male/female), the image of submission and cultural restrictions were attributed to women (FERREIRA; OLIVEIRA, 2019).

According to Kehl (2008), the historical evolution of the role of women in society is marked by the absence of rights since the beginning, and its trajectory is difficult to dialogue, because, when it comes to its history, the contents obtained are scarce, because there are more records of male landmarks.
Between humiliations and struggles, women began to apply for their rights, being driven by female figures of extreme impact at the time, as the French Christine Pisan, who contributed through her speeches in defense of gender equality, the American Ann Hutchinson, one of the first voices in the history of America to owe against the disparities suffered by women, and the British Mary Wollstonecraft, whose speech pointed to the ability of women to make their own decisions, express their wills and take responsibility for their particular acts and choices (DOMINGUES, 2020).

The feminist movement then emerges as a production of a critical reflection on the values and patterns pre-established to genders, denouncing the oppressive conditions experienced by women, which questions the superiority and domination imposed by men. It is a movement considered as a philosophical and political-social organization, which aims to fight for gender equality, freedom, female sorority and citizenship, women being their central action (FERREIRA; OLIVEIRA, 2020).

There are several understandings about "What is it?" and "What do you stand for?" feminism, possibly for social, religious and/or political issues. However, disinformation provides an inverse view of real feminist values, since it focuses on the rupture of rape culture, the hierarchization of the sexes, misogyny and sexism (CECCARELLI, 2017).

It is note point that the evolution of feminism and the achievements of women were possible by the encouragement and dedication of women, the first militants were mostly upper middleclass, who had access to studies because they were from elitist families, being possible, over time, the creation of small groups of feminist studies to facilitate the understanding of the less favored and it is possible to include women from different contexts for the movement. Thus, little by little feminism was reaching the most popular classes and categories with more specific demands (SANTOS et al., 2016).

Pereira (2010) points out that "[...] feminism has achieved legal recognition of women's equal rights and opportunities and $\mathrm{i}$ also look back to the victims that they may be victims, the other way they contribute mightily to the revaluation of the role that women play in society." On the other hand, there are still several challenges to be faced by women, because still many understand that the world is made of men and for men, where the figure of the woman is projected only in her shadow.

From this perspective, an approach to psychology can be discussed in the light of feminism, the so-called traditional existential phenomenology. Existentialism, from the perspective developed by Jean Paul Sartre, is a philosophical current that deconstructed some questions about the immutable and static essence of the human being, because they constitute rational beings and predetermined by their essence. Thus, it is believed that existence precedes the essence, that is, the individual becomes what he does daily with his existence (QUINAN, 2016).

Sartre (1987) states that "Man is nothing more than what he makes of himself", that is, we can infer that the constitution of the subject, at first, takes place through some processes, such as his existence, encounter with himself, his emergence in the world and finally, the ability to define 
himself in the world to which he is inserted (ORENGO; NETHERLANDS; GOTO, 2020).

The attitudes that permeate the human being to choose actions that give him meaning, will be related to the ability to remain conscious, being a combination of elements such as reality, capacity, possibility and potentiality. The consciousness of existing then occupies a place of centrality in existential doctrine and from this consciousness, the subject can see himself not as an object of chance, but as the author of the story itself (RAMOS; FERREIRA, 2020).

Existence as "being-in-the-world" in turn has a relationship with the individual and the external environment, being highlighted in four dimensions of existence: Physics (considered the natural world, which incorporates the relationship of the individual with the biological aspects of existence and with the environment); Social (which refers to the world of relationship with others, that is, of being-with, which provides the discovery of what one is, and one wants to be); Psychological (formed by the relationship with one's own, where subjective existence is demonstrated) and Spiritual (it is the universe of the relationship with the unknown, which has repercussions on the relationship with the idealized world, where the purpose of individual existence can be manifested) (CARDINALLI, 2015).

In existentialism, there is a concept called "being-in-theworld", which is implied when the individual ceases to be only in the world and becomes an active being in this environment. It is considered a constant restlessness with one another, in order not to lose its dignity of existence, the way the subject chooses "to be-in-the-world "through freedom of choice. These choices can be made depending on the future (which involves anxiety/fear of the unknown) or depending on the past (which concerns the culpability/awareness of missed opportunities) (CARDINALLI, 2015).

According to Sartre (1997) the individual who is considered "being-in-the-world", is not allowed to be static, that is, he finds himself in a constant search for ascension. Assuming that the subject is initially only "nothing", seen as indeterminate, it is the search for meaning that will cause the same, to each experience is constituted and build itself. This search for the meaning of life and things around it is present in the life of the human being, and can be seen as a "beingFor-himself", thinking being who questions and observes its reality and subjectivity, being possible to transform it.

In relation to the feminist movement, this discussion establishes relationships with the pragmatic questioning of "being-in-the-world", seeking is in congruence with the essence, in order to go against the social values already preestablished, which influence the way the subject perceives himself in the world, making him often a hostage of society without at least questioning it.

Another element that relates to the women activists of the feminist movement is the idea of freedom established by Camon (1993), where it is advocated that the human being as a free being, is able to decide and afford his own choices, which mean fighting for his own dignity. And ste researcher states that this is a radical attitude, so that either the subject lives full determinism or lives full freedom. In this bias, feminists chose absolute freedom, not complicacy, doing more than was offered and expected, demonstrating predominance in the desire for freedom (JOHANSONM, 2020).

Faced with this freedom of choice, fighting or settling down, the anguish of this freedom arises, because this libertarian condition implies making its own decisions and consequently to bear them. Although the human being wishes to be free, emerges in the anguish of the need to choose and thus, many focuses on trying to refuse freedom, attributing the power of choice to other people, in order not to bear their responsibilities. However, refusal to freedom is an exercise of freedom in itself, and its results also come from this choice (LIBERATO, 2021).

Anguish also arises as a functionality of consciousness, with the aim of awakening the responsibilities of the subject before his own actions. This human action can be seen as a reactive to the given state of things, being a possibility to build the idealized state, because a person exposed to a situation where it is necessary to determine a given option, freedom will be the determinant of the human condition (CAMON, 1993). Therefore, the anguish in this bias may contribute to the redirection of the individual to leave the way of stagnation, serving as a condition of freedom.

If anguish causes discomfort to the individual, on the other hand, it enables the rescue of his authentic existence. The authenticity according to Cabestan (2005) implies accepting the human condition as it is lived, to the point of confronting anxiety and the choice of its future, which will lead to the reduction of existential culpability. Authenticity is constituted by the awareness of the choice of an existential trajectory of its own, for which it is essential to take responsibility as opposed to justifying the consequences of the chosen acts. It is a dynamic and continuous process, in which the subject sees himself before his own charges and suffers all the pressure stemming from his life in society (EBLING, 2008).

Authenticity is characterized by the maturity of personal and social development, and the rescue of this characteristic occurs when the subject regains consciousness about his needs and fundamental in view of the options offered. On the other hand, inauthenticity can be expressed by the discourses and acts that are repeated by the mass, where the mass itself grants the place to what is unrelated, thus losing the awareness of existence (MOURA, 2019). In this sense, it is necessary that the individual does not allow himself to be a prisoner in the face of the influences of the social, because this attitude, makes him submit the appreciations of the environment to which he lives and not to what he aspires to be and what he wants for himself.

Some people in an attitude incoherent with themselves, end up yielding to inauthenticity and hide their anguish through victimization, this attitude is characterized as bad faith. They prefer to alienate their freedom by living in anguish, such that bad faith is directly related closely to the existentialist concepts of anguish and nausea of being. Existential nausea happens when there is the disgust of the world, from the moment the world swallows the "in-itself" (consciousness, personality) to affirm the desire of the majority (CAUBET, 1981).

In the relationship between individuals, the praxis of one recognizes that of the other, being extremely indispensable. 
The group is composed when a group of individuals is linked to a common praxis, which is conscious and free. In this perspective, this context can be related to social movements, especially the feminist movement, which was gradually gained from the joint union of women in search of their rights.

Based on these assumptions, it is understood that the woman will be what she makes of herself, whether historically, individually, collectively and culturally. It is estimated that through the knowledge of the feminist movement it is possible to provide women with more emphasis on their "being-in-theworld" and restlessness in society and can be affirmed that feminism and existentialism have an important connection.

\section{Feminism and Psychology}

It is necessary to highlight that psychology in general aims to promote a differentiated look to the subjects and their demands, where we seek to understand and study the mental states and processes of the behavior of the human being and their interactions. It is up to Psychology as a social commitment, when it comes to gender inequality, not to allow this practice to be repeated and standardized. On the contrary, debates and more information should be promoted about the dominant discourse of oppression of women, identifying and deconstructing social structures and personal and professional practices that support sexism, machismo and violence, serving as an instrument of social control (PIZZINATO; ALMEIDASECOND; UZIEL, 2020).

Thus, the psychologist must comply with the Code of Ethics that governs their conduct, serving as guidance and supervision. This Code determines several regulations, which delimit the responsibilities and duties of the psychologist, in order to promote guidelines for his actions. Among the issues established in this regulation, what is related to the theme of this reviews the first and sixth principle, consecutively, which emphasizes the performance of the psychology professional based on respect for human dignity and integrity and the development of strategies for the elimination of oppression sand segregations (CFP, 2005).

Article 2 of the Code of Ethics is warned that: "The psychologist is denied: a) To practice or be conniving with any acts that characterize negligence, discrimination, exploitation, violence, cruelty or oppression" (CFP, 2005), logo, psychology professionals through their ethical commitment and theoretical knowledge are subjected to these statements categorically, because their target audience is the human being, regardless of their ethnicity, religion, gender and age, and is intolerable in their function, attitudes of judgment, prejudice and discrimination, or being complicit in such practices of gender oppression.

However, it can be affirmed that the entire code of ethics is based on the values that underlie the Universal Declaration of Human Rights and the due practice of the profession will have to be supported by it. Article 1 of Human Rights rectifies that: "All human beings are born free and equal in dignity and rights. Endowed with reason and conscience, they must act with each other in a spirit of brotherhood"(UNIC, 2009). From this, it is understandable that any action that affects the human being in his dignity of rights and citizenship must be combated, because psychology as a science does not tolerate inequality, disrespect, intolerance in any aspect, especially in this context, women are specified.

\section{Conclusions}

This research has enabled a greater understanding of the historical evolution of women to this day, evidencing their trajectory which was fraught with many struggles and challenges. It can be seen that there were some achievements achieved by them, and that little by little, they were influencing several places to become visible before society.

Through the feminist movement and women activists of social movements, it was possible to guarantee greater rights such as civil rights, political rights and even direct on their bodies. Even so, there are still several issues to be addressed, to consider themselves a world of gender equality or with less oppression against women. However, it is worth noting that there have been advances and currently, there are laws that support women in an attempt to protect them against sexism.

It was proposed to relate feminism with existential psychology and to come across the vision of Sartre and other existential authors who defend some concepts, such as freedom, anguish, turn out to be, be-in-the-world, authenticity, inauthenticity and among others, it is understood that social movements, especially feminist, present a possible articulation with existentialism. This is because the people who participate in these actions, for the most part, have an use easiness in their essence, which allow them to choose full freedom rather than subjection, and stand in evidence their authenticity and attitude of being-in-the-world, being possible to assume their responsibilities and not being passive, before their incompleteness.

Finally, it is inferring that psychology as a science must have a differential look at gender issues, and its professionals need to have their performance according to the Code of Ethics, putting into practice the fight against oppression and violence, and providing greater discussions about feminism, as a possible tool of female empowerment. Therefore, it is estimated that the objectives pointed out in this article were achieved and it is necessary to further studies on the subject, due to the existence of few studies that address this correlation between psychology and the feminist movement.

\section{Acknowledgements}

I thank first to God, the author and consummate of my faith, and my parents Luciano Souza and Kathiane Moneta, who helped me in this important phase of my life. I also want to thank my dear husband Dimas Amaral, for all the support and encouragement and my advisor Fabiane Gonçalves, who contributes to this manuscript. Thank you so much!

\section{References}

[1] BARBOSA, K. M. S. Feminism and Female Emancipation: A study on the conception of the emancipation of black women in Bamidelê- Organization of Black Women of Paraíba. 2016. 
$112 \mathrm{f}$. Thesis (Master in Sociology) - Federal University of Paraíba, João Pessoa, 2016.

[2] CABESTAM, P. "Authenticité et mauvaise was: que meanifie ne pas être soi-même?"; in: Les Tempos Modernes: Notre Sartre, no. 632-633-634. Paris: Éditions Gallimard, p. 604-625, 2005.

[3] CAMON, V. A. A. Existential psychotherapy. 2.ed. São Paulo: Livraria Pioneiro Editora, 1993.

[4] CAMPOI, I. C. The book "women's rights and injustice of men" by Nísia Floresta: literature, women and Brazil of the 19th century. History, v. 30, n. 2, 2011.

[5] CARDINALLI, I. E. Heidegger: the study of human phenomena based on human existence as being-there (Dasein). Psycho. USP, v.26, n.2, 2015.

[6] CECCARELli, P. R. Psychoanalysis, sex and gender. Estud. psicanal. n.48, p. 135-146, 2017.

[7] FEDERAL COUNCIL OF PSYCHOLOGY - CFP. C OI say of Itis professional ethics of the psychologist3rdsoon. Brasilia: C.F.P, v. 1, 2005.

[8] DOMINGUES, S. G. A. A brief history of the emergence of feminism in Brazil. Electronic Journal of the Faculty of Law of Campos,v. 5 n. 1,p. 134-143, 2020.

[9] EBLING, M. Qualification of conscientious authenticity from self-conscientious therapy. Conscientia, v. 12, n. 1, 2008.

[10] FERREIRA, F.M., OLIVEIRA, C. P. The feminist movement and the crisis of masculinity: reflections from political psychology. Psychology Notebooks. v. 1, n. 2, p. 580600, 2019.

[11] GARCIA, C. A. Dissecting masculinity at the crossroads between psychoanalysis and gender studies. Psychology in Journal, v. 16, no. 1, p. 81-102, 2010

[12] GONÇALVES, R.M. P., YAMAMOTO, O. H. Theoretical and practical foundations of social psychology: a historical and necessary debate. Rev. psicol. polít. v.15.n.32, p. 17-31, 2015.

[13] JOHANSON, I.C. From object to subject: a feminist contribution to history and philosophy. Rev. Estud. Fem. v.28, n. 1,2020 .

[14] KEHL, M. That's a good one. Displacements of the feminine. 2. Ed. Rio de Janeiro: Imago, 2008.

[15] LIBERATO, E. S. O. Sex, gender \& feminism: for a contemporary vindication of women's rights. Rev. Estud. Fem. v.29, n.1, 2021

[16] MOURA, C. Between psychoanalysis and existentialism: the structuring of personality under condition. Psychology in Research Journal. V. 13, n. 2, 2019.

[17] OLIVEIRA, A. L. Nísia forest in "women's rights and injustice of men": feminism translation policy. DATAVENIA, v. 7, n. 6 , 2015.

[18] OLIVA, J. The Other from corporeity: the importance of the body in the situation of the woman in The Second Sex of Simone de Beauvoir. Feminist epistemology. v. 5, n. 9, 2014.

[19] ORENGO, F. V., HOLANDA, A. F., GOTO, T. A. Phenomenology and phenomenological psychology for Brazilian psychologists: an empirical understanding. Psycho.
Study. v.25, p. e45065, 2020

[20] PEREIRA, E. A. Social construction of the feminine and hermeneutic subject of daily life: theoretical reflections. Revista Educação e Linguagens, v. 1, n. 1, p. 24-45, 2012.

[21] PEREIRA, A. S., SHITSUKA, D.M., PARREIRA, F. J., Shitsuka, R. Metodologia da pesquisa científica. (1st ed.) -: UFSM, NTE, 2018. Available in: https://repositorio.ufsm.br/bitstream/handle/1/15824/Lic Com putacao_Metodologia-Pesquisa-Cientifica.pdf? sequence $=1$

[22] PEREIRA, F. C. Non-discrimination on grounds of sex. Recife: Liceu, 2010.

[23] PIZZINATO, A., ALMEIDA-SEGUNDO, D. S., UZIEL, A. P. Gênero e Sexuality: Análise das Publicações no Revista Psicologia: Ciência e Profissão (1995-2019). Psicol. cienc. prof. v.40, p. 1-17, 2020.

[24] QUINAN, C. L. Feminism, Existential. The Wiley Blackwell Encyclopedia of Gender and Sexuality Studies, p. 1-3, 2016.

[25] RAMOS, J. A., FERREIRA, N. S. An analysis of existentialism and identity in the metamorphosis, by Kafka. Scientific Journal of UniRios, 2020.

[26] SANTOS, L.C., CARVALHO, A.B., AMARAL, J. G., et al. Género, feminismo y psicología social en Brasil: análisis de la revista psicologia \& sociedade (1996-2010). Psycho. Soc. v. .28, n.3, p.589-603, 2016.

[27] SARTRE, J. P. Existentialism is a humanism. São Paulo. New Cultural, 1987

[28] SARTRE, J. P. Being and nothing: ontological phenomenology assay. Translation by Paulo Perdigão. $5^{\circ}$ ed, RJ: Vozes, 1997.

[29] SCHNEIDER, D. R. Sartre and clinical psychology. Florianópolis: Publisher of UFSC, 2011.

[30] SOUZA, A. L., THUROW, C. F., RODRIGUES, G. et al. Dialogues of existentialist psychology with the concept of territory. Rev. gestalt approach. v.26, n.3, p. 339-349, 2020.

[31] UNIC. Human rights declaration. Rio de Janeiro: Rio, 2009.

[32] VILARIM, F. R., GOMES, E.B. Human rights and access to justice: internet governance and the fourth wave of the feminist movement. Notebook of the Higher School of Public Management, Politics, Legal and Security.v. 3, n. 1, 2020.

[33] WITTEKIND, M. Women's empowerment: study of feminist manifestations on social networks through hashtags. 2016. $50 \mathrm{f}$. Monograph (Specialization) - Social Communication Course, Unijui, Rio Grande do Sul, 2016. Cap. 4. 